Biogeography

\title{
Jatropha curcas flowers from southern Mexico: chemical profile and morphometrics
}

\author{
Flores de Jatropha curcas del sur de México: perfiles químico y morfométrico \\ Julieta Grajales-Conesa ${ }^{\mathrm{a}, *}$, Lorena Aceves-Chong ${ }^{\mathrm{a}}$, Manuel Rincón-Rabanales ${ }^{\mathrm{a}}$, \\ Leopoldo Cruz-López ${ }^{\text {b }}$ \\ a Instituto de Biociencias, Universidad Autónoma de Chiapas, Boulevard Príncipe Akishino s/n. Col. Solidaridad 2000, 30798 Tapachula, Chiapas, Mexico \\ ${ }^{\mathrm{b}}$ El Colegio de la Frontera Sur, Unidad Tapachula, Carretera Ant. Aeropuerto, Km. 2.5, 30700 Tapachula, Chiapas, Mexico
}

Received 28 October 2015; accepted 15 August 2016

Available online 31 October 2016

\begin{abstract}
Jatropha curcas flowers from two localities in the Soconusco region, southern Mexico, were chemical and morphometrically analyzed: Camino a la Pita (CP) and Manuel Lazos (ML). Our results showed significant differences in floral volatile composition and flower morphology. A total of 30 compounds were identified; (E)- $\beta$-ocimene was the main compound in all flowers, followed by dendrolasin, $(\mathrm{Z}, \mathrm{E})$ - $\alpha$-farnesene, linalool, and (3Z)-hexenyl benzoate. (Z, E)- $\alpha$-farnesene was the first discriminant compound between flower sex and locations, followed by (3Z)-hexenyl benzoate, (cis)- $\beta$-elemenone and linalool based on the Gini index. Morphometrically, there were significant differences between study sites, where $\mathrm{CP}$ female flowers were smaller in sepal, petal length and gynoecium height. These phenotypic variations could be the consequence of the high genetic differentiation driven for the environmental conditions where these populations are grown.
\end{abstract}

(C) 2016 Universidad Nacional Autónoma de México, Instituto de Biología. This is an open access article under the CC BY-NC-ND license (http://creativecommons.org/licenses/by-nc-nd/4.0/).

Keywords: Piñon; Floral volatiles; Morphometric; Diversity; Phenotype

\section{Resumen}

En este estudio se analizaron química y morfométricamente flores de Jatropha curcas de dos localidades de la región Soconusco, del sur de México: Camino a la Pita (CP) y Manuel Lazos (ML). Nuestros resultados muestran diferencias significativas en la composición de volátiles florales y morfológicos. Se identificaron un total de 30 compuestos; (E)- $\beta$-ocimeno fue el principal compuesto en todas las flores, seguido por dendrolasin, (Z, E)- $\alpha$-farneseno, linalol y (3Z)-benzoato de hexenilo. El compuesto que discriminó ambos sexos de flores y sitios de estudio fue el (Z,E)- $\alpha$-farneseno, seguido por (3Z)-benzoato de hexenilo, (cis)- $\beta$-elemenona y linalol, basado en el índice de Gini. Asimismo, morfométricamente se observaron diferencias significativas entre ambas localidades; las flores femeninas de CP fueron más pequeñas en el tamaño del sépalo, pétalo y gineceo. Estas variaciones fenotípicas pueden ser consecuencia de la alta diferenciación genética debida a las condiciones ambientales donde estas plantas se encuentran.

(C) 2016 Universidad Nacional Autónoma de México, Instituto de Biología. Este es un artículo Open Access bajo la licencia CC BY-NC-ND (http://creativecommons.org/licenses/by-nc-nd/4.0/).

Palabras clave: Piñón; Volátiles florales; Morfométrico; Diversidad; Fenotipo

\section{Introduction}

\footnotetext{
* Corresponding author.

E-mail address: jugrajco79@gmail.com (J. Grajales-Conesa).

Peer Review under the responsibility of Universidad Nacional Autónoma de México.
}

Floral display consists of specific visual and olfactory signals, which serve as learning cues to attract pollinators. These floral signals have a similar role as in animals for mating in 
sexual reproduction, e.g., plants that have male and female flowers can respond differently to pollinator-mediated selection, and male flowers can be more attractive than female ones to pollinators or vice versa (Waelti, Page, Widmer, \& Schiestl, 2009; Whitney \& Federle, 2012). In some cases, these differences are related to chemical signaling emitted by plants, which is crucial in the ecology and evolution of plant-insect interactions (Ashman, Bradburn, Cole, Blaney, \& Raguso, 2005; Flamini, Cioni, \& Morelli, 2002). Nonetheless, knowledge about the relative importance of these traits in different pollination systems of species in high diversity areas in Latin America is little known. In Mexico there are some studies related to this chemical signaling and bees' interaction with industrial crops, such as rambutan and citrics (Aceves-Chong, Rincón-Rabanales, Cruz-López, \& Grajales-Conesa, 2015; Grajales-Conesa, Meléndez-Ramírez, Cruz-López, \& SánchezGuillén, 2012). However, there are some other emerging economical crops, like "piñón" (Jatropha curcas; Euphorbiaceae), which is native to Mexico and Central America, and considered as the most promising non-edible plant for biofuel production (Brittaine \& Lutaladio, 2010; Fresnedo-Ramírez, 2013; Ovando-Medina, Espinosa-García, Núñez-Farfán, \& Salvador-Figueroa, 2011; Salvador-Figueroa, Magaña-Ramos, Vázquez-Ovando, Adriano-Anaya, \& Ovando-Medina, 2014; Rincón-Rabanales et al., 2016). Studies performed in Mexico related to $J$. curcas pollination showed that fruits are produced by geitonogamy and xenogamy, where the stingless bees Scaptotrigona mexicana and Trigona (Tetragonisca) angustula are the most frequent visitors (Ovando-Medina et al., 2014). In particular, for J. curcas there is only one report on floral volatiles for plants grown in China, where Apis mellifera was the most important visitor and linalool was the major volatile constituent (Changwei, Kun, Chen, \& Yongyu, 2007; Changwei et al., 2013). On the other hand, floral morphology plays a key role and represents a communication channel between plants and floral visitors. In India, J. curcas floral studies revealed that they are unisexual and male and female flowers are produced in the same inflorescence, being female flowers larger (Kaur, Dhillon, \& Gill, 2011). Notwithstanding, given the little basic knowledge of floral and reproductive biology of J. curcas in its center of origin with a high diversity of genotypes, this study represents a significant contribution to the agricultural management understanding of $J$. curcas in the tropics. Thus, it is crucial to analyze the floral volatiles and morphology of J. curcas under natural conditions, which may help to understand the insect-plant interaction system of this species in the future.

\section{Materials and methods}

Jatropha curcas is monoecious with inflorescences of unisexual flowers, where female flowers open before the male ones. In the Soconusco region, J. curcas has 3 flowering peaks $(80 \%)$ in the months of April, May-June and September. This plant produces an average of 1.25 inflorescences per branch, with the proportion of female/male flowers 1:60, which regularly open over an average period of 15 days (Adriano-Anaya et al., 2016; Rincón-Rabanales et al., 2016). In particular, for this region the native stingless bees Scaptotrigona mexicana (Guérin-Meneville) and Trigona (Tetragonisca) angustula (Latreille) are the most frequent visitors (Rincón-Rabanales et al., 2016).

Jatroha curcas flowers were collected during the flowering period from June to July 2014 in plants growing as living fences (10 years old). These living fences are located in the Soconusco region; "Camino a la Pita" in Tapachula municipality (CP; 14 50'36" N, 92 17'04" W) and "Manuel Lazos" in Tuxtla Chico municipality (ML; $14^{\circ} 58^{\prime} \mathrm{N}, 92^{\circ} 11^{\prime} 5^{\prime \prime} \mathrm{W}$ ). CP is located in the plains subregion with a subhumid weather and abundant rains during summer (the average annual rain is $2,197 \mathrm{~mm}$ ), average temperature of $27.5^{\circ} \mathrm{C}$ and $90 \mathrm{~m}$ asl, a region surrounded by livestock areas and crops (corn, soybean, banana, and mango). In contrast, ML is located in a mountainside area with a humid weather and abundant rains during summer-autumn (the average annual rain is $4,259 \mathrm{~mm}$ ), average temperature of $26^{\circ} \mathrm{C}$ and $431 \mathrm{~m}$ asl, a region with intercropping of coffee-rambutanbanana, and remnants of secondary vegetation with primary vegetation relicts within cultivars (García, 1988).

First, we randomly collected 6 panicles from different flowering plants in each study site. Then male and female J. curcas flowers were carefully removed with a pair of forceps, and were separately confined in $100 \mu \mathrm{L}$ glass containers $(n=10$ flowers for each sex by panicles, 120 flowers per study site). After this, they were transported to the laboratory. A solid phase microextraction (SPME) device fitted with a fiber coating of $50 \mu \mathrm{m}$ Divinylbenzene/Carboxen/Polydimethyl siloxane (DVB/CAR/PDMS) (Supelco, Bellefonte, PA, USA) was introduced at the top of each glass container. Each coated fiber exposed to the internal headspace was left for $10 \mathrm{~min}$ to collect the volatiles. After sampling, fibers were removed and inserted into the injector port of a gas chromatographmass spectrometer (GC-MS) and desorbed during 1 min. In another experiment, volatiles emitted by J. curcas inflorescences were collected in situ: panicles were covered with an airtight seal bag $(16.7 \mathrm{~cm} \times 15 \mathrm{~cm})$ where the SPME fiber could enter without touching the flowers during $30 \mathrm{~min}$. After this, the SPME fibers were immediately inserted into the injector port of a GC-MS. This last experiment was performed in order to assure that volatiles reported in this study corresponded with the flowers, and not by contaminants or by cutting effect.

Gas chromatography-mass spectrometry was carried out with a Gas Chromatograph-Mass Spectrometer SHIMADZU GCMSQT8040 (Tokyo, Japan). The SPME samples were analyzed by using a non-polar capillary column (DB-5MS, $30 \mathrm{~m} \times 0.25 \mathrm{~mm}$, i.d. $0.25 \mu \mathrm{m}$, J\&W Scientific). Temperature of column was programmed from $50^{\circ} \mathrm{C}$ to $280^{\circ} \mathrm{C}$ at $15^{\circ} \mathrm{C} / \mathrm{min}$. The carrier gas was helium at $1 \mathrm{~mL} / \mathrm{min}$. Preliminary identification of compounds was carried out using the NIST 2012 spectral library or mass spectral data, as well as their Kovat's Index reported in literature. Confirmation of the identification of some compounds was done by comparing their retention times and mass spectral data with those of synthetic compounds. The relative percentage of the components was calculated from the sum of the recorded peaks. 
Table 1

Mean relative abundance of male and female floral volatiles from Jatropha curcas in the Soconusco region $( \pm \mathrm{SD})$. KI $=\mathrm{Kovats}$ index.

\begin{tabular}{|c|c|c|c|c|c|c|}
\hline & \multirow[t]{2}{*}{ Compounds } & \multirow[b]{2}{*}{ KI } & \multicolumn{2}{|c|}{ Camino a la Pita } & \multicolumn{2}{|c|}{ Manuel Lazos } \\
\hline & & & Female & Male & Female & Male \\
\hline 1 & (Z)- $\beta$-Ocimene & 1030 & $2.22 \pm 0.94$ & $3.17 \pm 0.76$ & $3.12 \pm 1.58$ & $2.84 \pm 0.97$ \\
\hline 2 & (E)- $\beta$-Ocimene & 1042 & $43.76 \pm 18.00$ & $59.55 \pm 16.57$ & $31.29 \pm 14.13$ & $46.27 \pm 12.14$ \\
\hline 3 & (cis)-Furanoid linalool oxide & 1072 & $0.26 \pm 0.12$ & $0.18 \pm 0.10$ & $0.32 \pm 0.46$ & $0.56 \pm 0.39$ \\
\hline 4 & (trans)-Furanoid linalool oxide & 1089 & $0.44 \pm 0.43$ & $0.61 \pm 0.34$ & $2.43 \pm 1.86$ & $1.44 \pm 0.91$ \\
\hline 5 & Linalool & 1099 & $7.11 \pm 1.83$ & $3.85 \pm 1.46$ & $4.36 \pm 3.19$ & $4.51 \pm 3.21$ \\
\hline 6 & 2-Ethenyl-1,1-dimethyl-3-methylene-cyclohexane, & 1112 & $4.94 \pm 1.59$ & $3.02 \pm 0.95$ & $3.78 \pm 2.22$ & $1.49 \pm 1.10$ \\
\hline 7 & (E,E)-2,6-Dimethyl-1,3,5,7-octatetraene & 1115 & $0.15 \pm 0.10$ & $0.22 \pm 0.09$ & $0.13 \pm 0.11$ & $0.11 \pm 0.08$ \\
\hline 8 & allo-Ocimene & 1131 & $0.27 \pm 0.23$ & $0.29 \pm 0.08$ & $0.27 \pm 0.24$ & $0.23 \pm 0.15$ \\
\hline 9 & (4Z)-Hexenyl butanoate & 1153 & $0.48 \pm 0.35$ & $0.52 \pm 0.31$ & $0.09 \pm 0.09$ & $0.09 \pm 0.09$ \\
\hline 10 & (cis)-Pyranoid linalool oxide & 1181 & $0.08 \pm 0.07$ & $0.04 \pm 0.04$ & $0.34 \pm 0.27$ & $0.20 \pm 0.16$ \\
\hline 11 & (trans)-Pyranoid linalool oxide & 1185 & $0.28 \pm 0.24$ & $0.19 \pm 0.13$ & $0.53 \pm 0.32$ & $0.29 \pm 0.28$ \\
\hline 12 & (3Z)-Hexenyl-2-methyl butanoate & 1230 & $5.58 \pm 2.81$ & $5.36 \pm 1.78$ & $1.47 \pm 0.61$ & $1.83 \pm 1.02$ \\
\hline 13 & (3Z)-Hexenyl-3-methyl butanoate & 1237 & $0.70 \pm 0.64$ & $2.17 \pm 2.95$ & $0.89 \pm 0.99$ & $0.32 \pm 0.25$ \\
\hline 14 & Unknown ester & 1385 & $3.96 \pm 2.97$ & $1.54 \pm 0.85$ & $1.18 \pm 0.49$ & $4.87 \pm 8.17$ \\
\hline 15 & $\alpha$-Copaene & 1393 & $0.30 \pm 0.26$ & $0.13 \pm 0.10$ & $1.43 \pm 1.02$ & $0.76 \pm 0.55$ \\
\hline 16 & $\beta$-Cubebene & 1404 & $0.22 \pm 0.16$ & $0.05 \pm 0.03$ & $0.81 \pm 0.55$ & $0.48 \pm 0.43$ \\
\hline 17 & (Z)-Jasmone & 1414 & $0.60 \pm 0.35$ & $0.58 \pm 0.41$ & $1.17 \pm 0.54$ & $1.14 \pm 0.83$ \\
\hline 18 & (E)- $\alpha$-Caryophyllene & 1444 & $0.34 \pm 0.27$ & $0.32 \pm 0.31$ & $0.73 \pm 0.58$ & $0.40 \pm 0.34$ \\
\hline 19 & $\beta$-Copaene & 1452 & $0.29 \pm 0.44$ & $0.07 \pm 0.04$ & $0.43 \pm 0.27$ & $0.16 \pm 0.13$ \\
\hline 20 & $(Z)-\beta$-Farnesene & 1459 & $0.98 \pm 1.07$ & $0.88 \pm 1.48$ & $0.97 \pm 0.42$ & $0.65 \pm 0.33$ \\
\hline 21 & $\alpha$-Himachalene & 1480 & $0.18 \pm 0.16$ & $0.17 \pm 0.20$ & $0.47 \pm 0.31$ & $0.27 \pm 0.25$ \\
\hline 22 & $(\mathrm{Z}, \mathrm{E})-\alpha$-Farnesene & 1494 & 0.00 & 0.00 & $11.44 \pm 6.21$ & $6.52 \pm 4.59$ \\
\hline 23 & Germacrene D & 1504 & $0.90 \pm 1.00$ & $0.60 \pm 0.59$ & $2.53 \pm 1.60$ & $1.42 \pm 1.25$ \\
\hline 24 & $(\mathrm{E}, \mathrm{E})-\alpha$-Farnesene & 1511 & $6.94 \pm 3.16$ & $5.77 \pm 3.83$ & $8.90 \pm 3.69$ & $8.47 \pm 3.67$ \\
\hline 25 & $\gamma$-Cadinene & 1538 & $1.69 \pm 1.77$ & $0.31 \pm 0.36$ & $2.85 \pm 0.84$ & $2.52 \pm 2.25$ \\
\hline 26 & Hexyl benzoate & 1563 & $1.13 \pm 1.19$ & 0.00 & 0.00 & 0.00 \\
\hline 27 & Nerolidol & 1572 & $4.01 \pm 2.43$ & $4.06 \pm 3.49$ & $4.79 \pm 1.63$ & $4.06 \pm 0.95$ \\
\hline 28 & Dendrolasin & 1582 & $5.54 \pm 4.70$ & $2.79 \pm 3.86$ & $9.82 \pm 5.35$ & $3.45 \pm 3.00$ \\
\hline 29 & (3Z)-Hexenyl benzoate & 1594 & $6.66 \pm 5.26$ & $3.53 \pm 2.88$ & $0.69 \pm 0.51$ & $2.88 \pm 2.88$ \\
\hline 30 & (cis)- $\beta$-Elemenone & 1601 & 0.00 & 0.00 & $2.76 \pm 1.36$ & $1.77 \pm 1.52$ \\
\hline
\end{tabular}

We selected 2 panicles in 10 trees in the 2 study sites, and the number of female and male flowers per panicle was counted $(n=20$ panicles per site). Separately, we also collected 15 flowers of each sex in each study site ( $n=30$ flowers per site). We measured sepal and petal length, and gynoecium height with a reading scale ruler, directly from structures photographed with a digital camera mounted on a stereoscopic microscope (stereomicroscope Carl Zeiss STEMI 2000c; Zeiss camera AXIO CAM MRC, software Zen 2011, E206588).

Jatropha curcas floral volatiles composition was compared among all individuals by a principal coordinate analysis to determine possible associations between sexes and study sites (Camino a la Pita and Manuel Lazos). In addition, the Gini index was also calculated to evaluate the relative contribution of each volatile identified. All statistical analyses were performed in $\mathrm{R}$ v3.02 (RF) (R Development Core Team, 2012) with a multidimensional scaling function in the Random Forest Package (Liaw \& Weiner, 2002). Morphological data were analyzed by a General Linear Model (GLM) with 2-factor interaction, where one factor was sex and the other one was study site. The interaction $\operatorname{sex} *$ study sites was verified with the assumption of normality $(p<0.05)$. When significant differences were found data were analyzed with an Anova and a $t$-Student to compare sepal, petal length and gynoecium height respectively $(p<0.005)$. All these analysis were performed with the SAS software (v. 9.1.3).

\section{Results}

The chemical composition of female and male J. curcas flowers from the 2 study sites is summarized in Table 1 . A total of 30 compounds were identified; (E)- $\beta$-ocimene was the major volatile in all flowers, followed by dendrolasin, $(\mathrm{Z}$, E)- $\alpha$-farnesene, linalool, and (3Z)-hexenyl benzoate. Both sexes emitted most of the compounds but in different quantities, for example (E)- $\beta$-ocimene was the major compound in both study sites, but registered higher peak areas in male flowers (CP: $59.55 \%$ and ML: $46.27 \%$ ) than in female flowers (CP: $43.76 \%$ and ML: $31.26 \%$ ).

\section{Differences between sexes and sites}

Our results showed that (Z,E)- $\alpha$-farnesene was the first discriminant compound between flower sexes and locations (CP and ML), followed by (3Z)-hexenyl benzoate, (cis)- $\beta$ elemenone and linalool based on the Gini index (Fig. 1a and b).

The coordinate analysis between the locations and the group of flowers (Fig. 1a) showed that Dim1 explained the discrimination in female flowers ( $\mathrm{x}$ axis) and the male flowers from $\mathrm{CP}$ (y axis), meanwhile Dim 2 explained the geographical separation of the group of flowers (flowers from $\mathrm{CP}$ in the left side, 

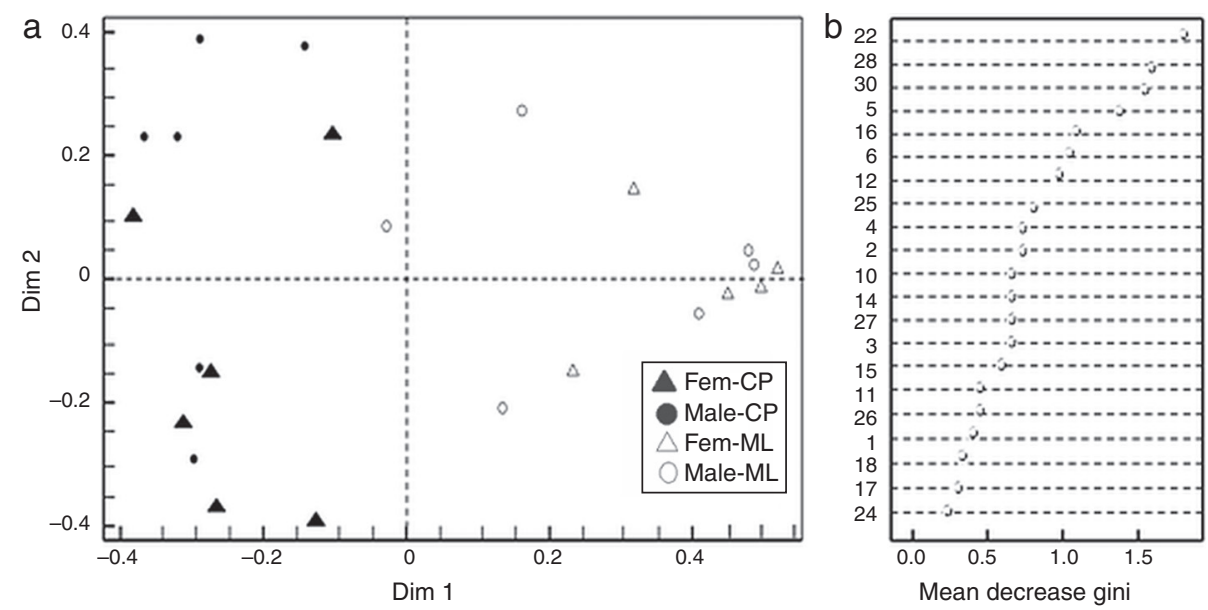

Figure 1. (a) Discrimination between Jatropha curcas flower sexes from the two study sites; Fem-CP, female flowers from Camino a la Pita (CP), Male-CP, male flowers from CP, Fem-ML, female flowers from Manuel Lazos (ML) and male-ML, male flowers from ML. Plot based on RF and Gini index; Dim 1 and 2 explained $57.3 \%$ of proximity. (b) Mean decrease Gini Index, where numbers correspond to chemical composition of J. curcas female and male flowers summarized in Table 1.
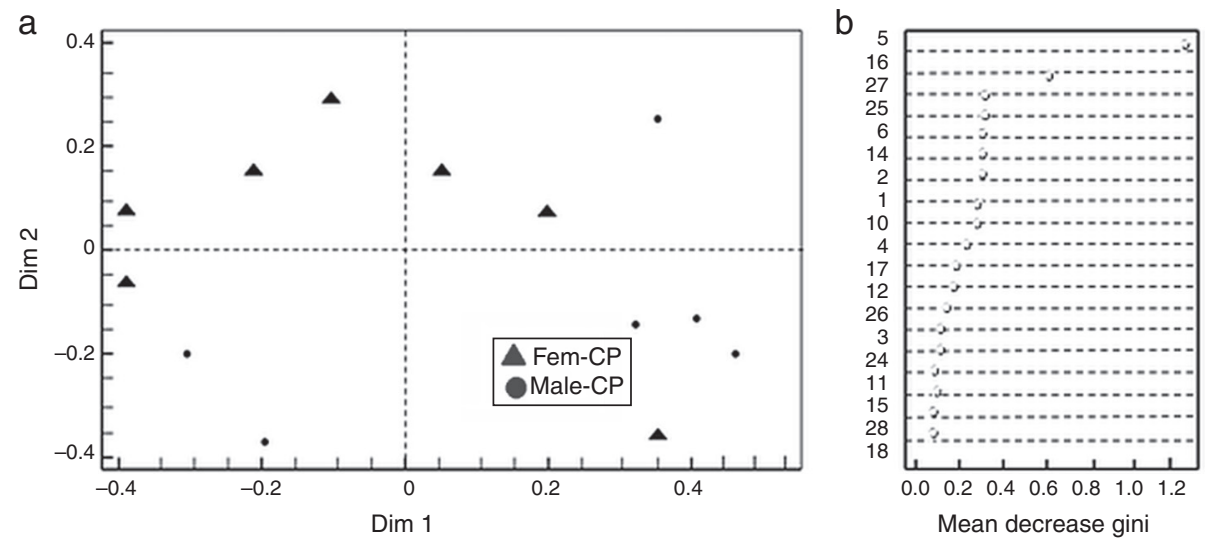

Figure 2. (a) Discrimination between Jatropha curcas flower sexes from Camino a la Pita (CP); Fem-CP, female flowers and Male-CP, male flowers. (b) Mean decrease Gini Index, where numbers correspond to chemical composition of $J$. curcas female and male flowers summarized in Table 1.

and flowers from ML in the right side), where female and male flowers from ML were more similar.

Based on the Gini index revealed that linalool was the compound that best differentiated flower sexes in $\mathrm{CP}$, followed by $\beta$-cubebene and dendrolasin (Fig. 2b). The coordinate analysis explained the $99.39 \%$ of Dim 1 and Dim 2 contribution
(Fig. 2a). In contrast, (3Z)-hexenyl benzoate differentiated flower sexes in ML, followed by 2-ethenyl-1, 1-dimethyl-3methylene-cyclohexane, dendrolasin and (cis)-furanoid linalool oxide (MDS, Fig. 3b). The principal coordinate analysis in RF, explained $95.90 \%$ of Dim 1 and Dim 2 contribution (MDS Fig. 3a). The confusion matrix showed that female
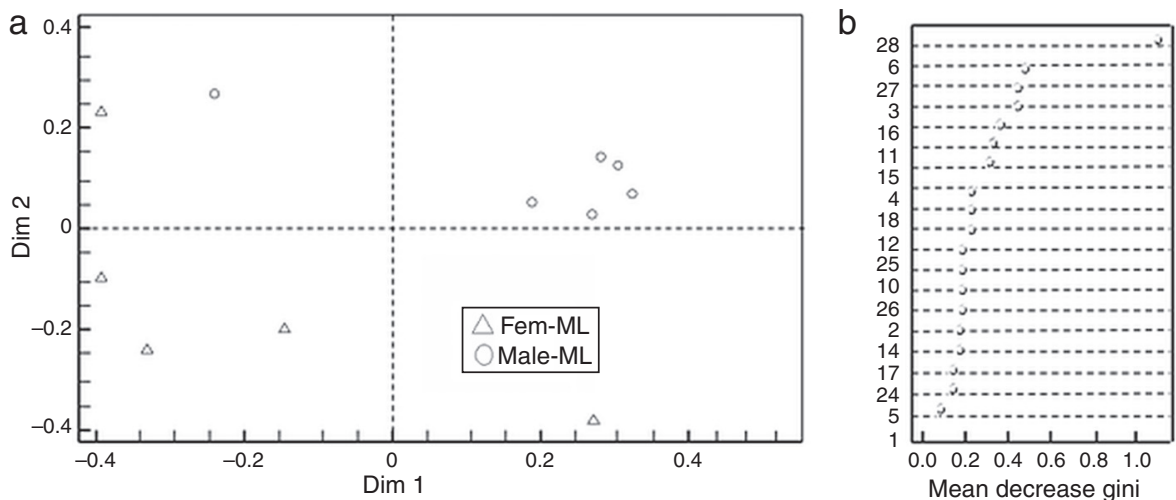

Figure 3. (a) Discrimination between Jatropha curcas flower sexes from Manuel Lazos (ML); Fem-ML, female flowers and Male-ML, male flowers. (b) Mean decrease Gini index, where numbers correspond to chemical composition of J. curcas female and male flowers summarized in Table 1. 

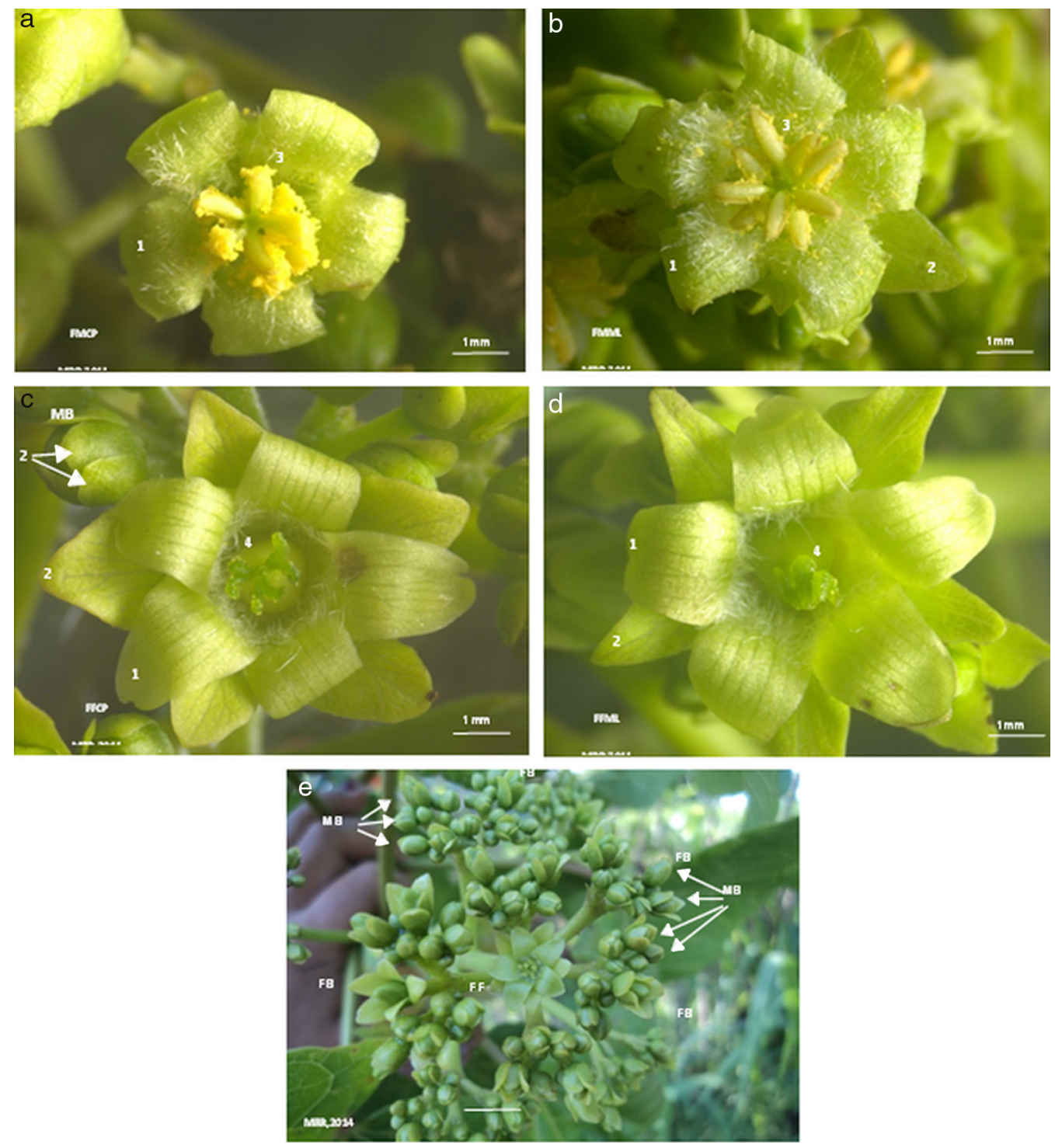

Figure 4. Jatropha curcas flowers from Camino la Pita (CP) and Manuel Lazos (ML); (a) male flower from CP, (b) male flower from ML, (c) female flower from CP, (d) female flower from ML, and (e) inflorescence with female flowers (FF), female button (FB) and male button (MB). $(1=$ Petal, $2=$ Sepal, $3=$ Anther, $4=$ Stigma, $\mathrm{G}=$ gynoecium).

flowers were $80 \%$ correctly classified, and male flowers $84 \%$, respectively.

We observed that female flowers opened first ( $48 \mathrm{~h}$ before) than male flowers (Fig. 4a-e), also that some inflorescences had only male flowers; male flower number was higher (39195 flowers) than female flowers $(0-18$ flowers $)(p<0.001)$. We did not find significant differences in the number of male flowers in both study sites (CP, $123.5 \pm 60.5$; ML, $147.2 \pm 56.7$; $p>0.05$ ), or in female flowers (CP, 7.6 \pm 4.4 ; ML, $8.7 \pm 5.3$; $p>0.05)$. Particularly, in this region of southern Mexico we observed that $J$. curcas flowers opened at $08: 00 \mathrm{~h}$, with a maximum aperture of female $(64.29 \%)$ and male flowers $(55.75 \%)$ at 09:00 h; first female flowers opened (for 8 days), and then after the second day of female flowers opening, male flowers started (for 13 days) (Ovando-Medina et al., 2014).

Moreover, we registered that $\mathrm{CP}$ female flowers were significantly smaller in sepal length $(t-$ test: $t=6.33, \mathrm{df}=28, p<0.001$,
$\mathrm{CP}, 1.80 \pm 0.37 ; \mathrm{ML}, 2.75 \pm 0.42)$, petal length $(t-$ test: $t=8.05$, $\mathrm{df}=28, p<0.001, \mathrm{CP}, 2.42 \pm 0.20 ; \mathrm{ML}, 3.05 \pm 0.22)$ and gynoecium height $(t-$ test: $t=7.01, \mathrm{df}=28, p<0.001, \mathrm{CP}, 1.50 \pm 0.21$; ML, $2.03 \pm 0.18$ ) (Fig. 5a and b). The GLM analysis showed a significant effect between sexes and study sites for sepal length (GLM: sex* study site: $F_{1,56}=7.56, p=0.008$ ) and petal length (GLM: sex* study site: $\left.F_{1,56}=66.64, p=0.0001\right)$.

\section{Discussion}

The compounds identified in this study are commonly known as being responsible for fresh and floral odors in flowers (Bertrand, Comte, \& Piola, 2006), for example; E- $\beta$-ocimene is found in Snapdragon flowers (Dudareva et al., 2000; Raguso \& Pichersky, 1995), linalool and linalool oxide (pyran form) being the most abundant compounds in Clarkia breweri (Raguso \& Pichersky, 1995). 

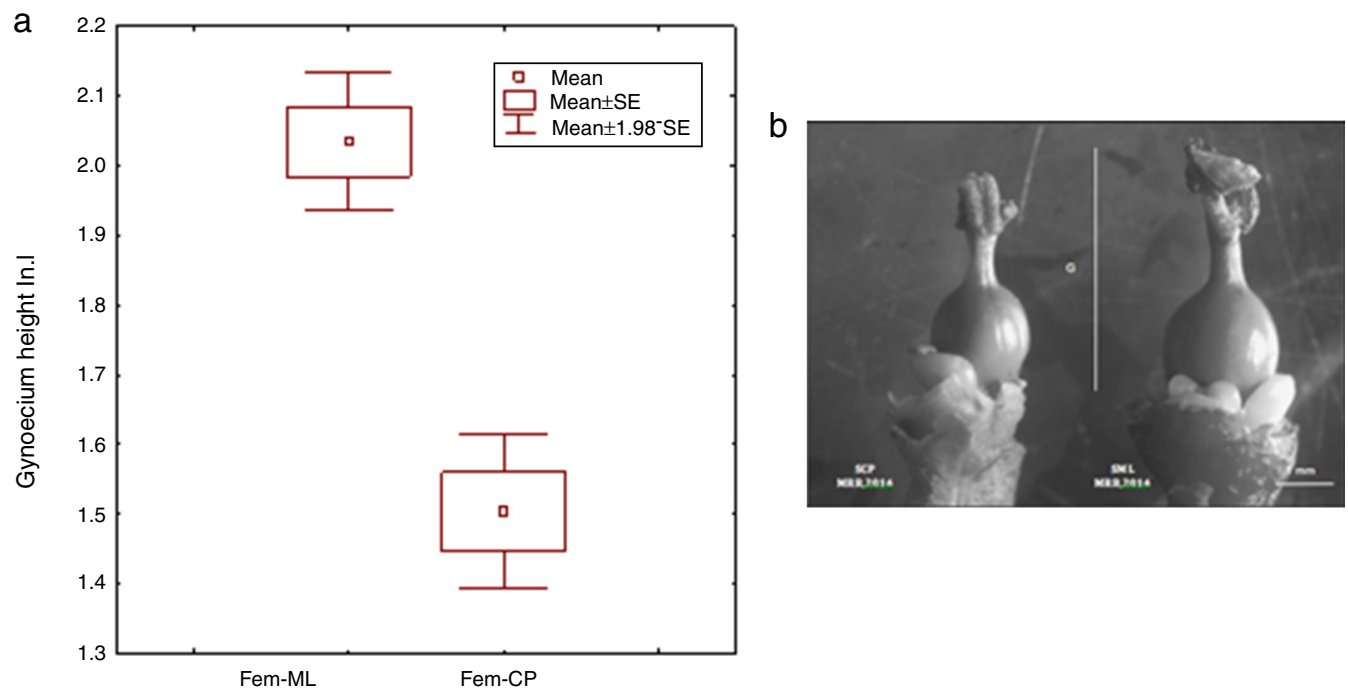

Figure 5. (a) Gynoecium height (Ln-1) in Jatropha curcas female flowers from both study sites; Manuel Lazos (Fem-ML) and Camino a la Pita (Fem-CP). (b) Differences observed in gynoecium from CP (SCP) and ML (SML).

Our results agree with the floral volatiles reported by Changwei et al. (2013) in China, where $\beta$-ocimene and linalool were present in $J$. curcas flowers, but differed in quantities, whereas our data showed higher values. These differences in relative abundance but not in chemical composition are also reported in 16 species of Clusia (Nogueria, Bittrich, Shepherd, Lopes, \& Marsaioli, 2001). Differences related to intraspecific variation were also reported by Azuma, Totoya, and Asakawa (2001) in Magnolia kobus flowers, who observed high quantitative and qualitative variation in floral scent chemistry among individuals from 32 study sites in Japan, and in Salix flowers (Füsel, Dötterl, Jürgens, \& Aas, 2006), which could provide specific signals that guide pollinators and contribute to the reproductive isolation of compatible and concurring species.

Chemical variation between populations may be the result of adaptation to local pollinators, thus chemical constancy of the floral scent within a population would be maintained (Azuma et al., 2001). These chemical differences could be also related to environmental conditions (temperature, humidity and light intensity), and genetic variation. In particular, in the Soconusco region, Ovando-Medina, Sánchez-Gutiérrez et al. (2011) and Salvador-Figueroa et al. (2014), reported a greater variation within populations from this study area, in contrast with worldwide populations.

Interestingly, we found that some compounds are unique to each sex, for example, hexyl benzoate was detected only in CP female flowers, and (Z,E)- $\alpha$-farnesene and (cis)- $\beta$-elemenone only in ML flowers both sexes. These differences in volatile emission between male and female flowers of J. curca could be related to insect visitors or pollinators. Similarly, in a gynodioecious wild strawberry (Fragaria virginiana), emission rates and floral scent composition in female and hermaphrodite flowers was compared to determine the source of sexually dimorphic odor and pollinator responses (Ashman et al., 2005). It was also found that pollinators preferred the scent of hermaphrodite flowers over those of females, besides that scent is an important modulator of pollinator behavior.
Based on morphology, our results agree with Saturnino, Pacheco, Kakida, Tominaga, and Goncalvez (2005), who reported that $J$. curcas female flowers opened before males in the same inflorescence, asyncronicly. Thus, our data suggest a pattern to facilitate the xenogamy process in these 2 study sites in Mexico, but it needs to be proven. Nonetheless, our results differed from studies performed in India by Raju and Ezradanam (2002) and Kaur et al. (2011), who observed in J. curcas populations from different geographical regions that male flowers opened first and in high number during blooming time within 11 days, meanwhile female flowers opened the second or sixth day after them. Changwei et al. (2007), observed a similar pattern in flower opening, but female flowers opened in high number after the third and fifth day, and some female flowers open first in some inflorescences, which could promote xenogamy instead of geitonogamy. On the other hand, Paiva-Neto, Brenha, Freitas, Zuffo, and Alvarez (2010) in Brazil observed a similar opening pattern as in India and China, as an alternative of natural geitonogamy.

Morphological differences have been also reported by Adriano-Anaya et al. (2016) and Ovando-Medina et al. (2013), who analyzed $J$. curcas floral variability in populations from the South of Mexico and observed differences between populations from Frontera and Soconusco, Chiapas (male flower diameter, female petal length and male nectary length). They discussed that these differences are due to physical barriers between these 2 populations, and mentioned that floral characters of $J$. curcas from Mexico are highly variable among accessions.

In conclusion, our results showed that there is intraspecific variation in these 2 populations, as in female and male flowers, in floral volatiles and floral morphology, as well we observed a tendency in J. curcas populations from the humid tropics of Mexico to promote xenogamy and minimize geitonogamy. Moreover, due to this chemical and morphological variation within and between populations, we could be able to consider them as 2 ecotypes, established in contrasting tropical environments in the Soconusco region. 
Finally, these results are particularly relevant for the conservation of $J$. curcas populations, in the context of habitat deterioration registered in Mesoamerica, therefore further studies are required to preserve and use J. curcas germplasm in future biodiesel production.

\section{Acknowledgements}

We wish to thank MC Javier Valle-Mora for his support in the data analysis, MEd Angélica Cordoba-Meza and MEd Jannette Dolly Carrión Rodríguez for their proof-reading and corrections to the manuscript, Cocytech, MC Antonio Santiesteban-Hernández for his technical support, and Conacyt project INFR-2014-01 by providing resources to get new GC-MS.

\section{References}

Aceves-Chong, L., Rincón-Rabanales, M., Cruz-López, L., \& Grajales-Conesa, J. (2015). Caracterización química y morfométrica de flores de rambután (Nephelium lappaceum). In X Congreso de Biotecnología "Chiapas 2015”, 27-29 May, Tuxtla Gutiérrez, Chiapas.

Adriano-Anaya, M., Pérez-Castillo, E., Salvador-Figueroa, M., Ruíz-González, S., Vázquez-Ovando, A., Grajales-Conesa, J., et al. (2016). Sex expression and floral diversity in Jatropha curcas: a population study in its center of origin. PeerJ, 4, e2071. http://dx.doi.org/10.7717/peerj.2071

Ashman, T., Bradburn, M., Cole, D., Blaney, B., \& Raguso, R. (2005). The scent of a male: the role of floral volatiles in pollination of a gender dimorphic plant. Ecology, 86, 2099-2105.

Azuma, H., Totoya, M., \& Asakawa, Y. (2001). Intraspecific variation of floral scent chemistry in Magnolia kobus DC (Magnoliaceae). Journal of Plant Research, 114, 11-422.

Bertrand, C., Comte, G., \& Piola, F. (2006). Solid-phase microextraction of volatile compounds from flowers of two Brunfelsia species. Biochemical Systematics and Ecology, 34, 371-375.

Brittaine, R., \& Lutaladio, N. (2010). Jatropha: a smallholder bioenergy crop. The potential for pro-poor development. Rome: Food and Agriculture Organization of the United Nations.

Changwei, L., Kun, L., Chen, Y., \& Yongyu, S. (2007). Floral display and breeding system of Jatropha curcas L. Forest Science and Practice, 9, 114-119.

Changwei, L., Zachary, H., Kun, L., Xiaoming, C., You, C., \& Yongyu, S. (2013). EAG responses of Apis cerana to floral compounds of a biodiesel plant, Jatropha curcas (Euphorbiaceae). Journal of Economic Entomology, 106, 1653-1658.

Dudareva, N., Murfitt, L., Mann, C., Gorenstein, C., Kolosova, N., Kish, C., et al. (2000). Developmental regulation of methyl benzoate biosynthesis and emission in snapdragon flowers. Plant Cell, 12, 949-961.

Flamini, G., Cioni, P., \& Morelli, I. (2002). Differences in the fragances of pollen and different floral parts of male and female flowers of Laurus nobilis. Journal of Agricultural Food and Chemistry, 50, 4647-4652.

Fresnedo-Ramírez, J. (2013). The floral biology of Jatropha curcas L. - a review. Tropical Plant Biology, 6, 1-15.

Füsel, U., Dötterl, S., Jürgens, A., \& Aas, G. (2006). Inter- and intraspecific variation in floral scent in the genus Salix and it implication for pollination. Journal of Chemical Ecology, 33, 749-765.
García, E. (1988). Modificaciones al sistema de clasificación climática de Köppen. Mexico, D.F.: Universidad Nacional Autónoma de México.

Grajales-Conesa, J., Meléndez-Ramírez, V., Cruz-López, L., \& SánchezGuillén, D. (2012). Effect of citrus floral extracts on the foraging behavior of Scaptotrigona pectoralis. Revista Brasileira de Entomologia, 56, 76-80.

Kaur, K., Dhillon, G., \& Gill, R. (2011). Floral biology and breeding system of Jatropha curcas in north-western India. Journal of Tropical Forest Science, 23, 4-9.

Liaw, A., \& Weiner, M. (2002). Classification and regression by random Forest. R News, 2, 18-22.

Nogueria, P., Bittrich, V., Shepherd, G., Lopes, A., \& Marsaioli, A. (2001). The ecological importance of flowers volatiles of Clusia species (Guttiferae). Phytochemistry, 56, 443-452.

Ovando-Medina, I., Adriano-Anaya, L., Vázquez-Ovando, A., Ruíz-Gonzalez, S., Rincón-Rabanales, M., \& Salvador-Figueroa, M. (2013). Genetic diversity of Jatropha curcas in Southern Mexico. In B. Bahadur, M. Sujatha, \& N. Carels (Eds.), Jatropha, challenges for a new energy crop. New York: Springer.

Ovando-Medina, I., Espinosa-García, F., Núñez-Farfán, J., \& SalvadorFigueroa, M. (2011). State of the art of genetic diversity research in Jatropha curcas. Scientific Research Essays, 6, 1709-1719.

Ovando-Medina, I., Rincón-Rabanales, M., Adriano-Anaya, L., Ruíz-Gonzalez, S., Vazquez-Ovando, A., \& Salvador-Figueroa, M. (2014). Stingless bees are efficient pollinators of the biofuel plant Jatropha curcas (L.) (Euphorbiaceae) within its native range. Journal of Ecosystem Ecography, 4, 3.

Ovando-Medina, I., Sánchez-Gutiérrez, A., Adriano-Anaya, L., EspinosaGarcía, F., Núñez-Farfán, J., \& Salvador-Figueroa, M. (2011). Genetic diversity in Jatropha curcas populations in the State of Chiapas, Mexico. Diversity, 3, 641-659.

Paiva-Neto, V. B., Brenha, J. A. M., Freitas, F. B., Zuffo, M. C. R., \& Alvarez, R. C. (2010). Aspectos da biologia reproductiva de Jatropha curcas L. Ciência e Agrotecnologia, 34, 558-563.

R Development Core Team. (2012). R: a language and environment for statistical computing. R Foundation for Statistical Computing. Retrieved on September 20th from: http://www.R-project.org/

Raguso, R., \& Pichersky, E. (1995). Floral volatiles from Clarkia breweri and C. concinna (Onagraceae): recent evolution of floral scent and moth pollination. Plant Systematics and Evolution, 194, 55-67.

Raju, S., \& Ezradanam, V. (2002). Pollination ecology and fruiting behaviour in a monoecious species, Jatropha curcas L. (Euphorbiaceae). Current Science, 83, 1395-1398.

Rincón-Rabanales, M., Vargas-López, L., Adriano-Anaya, L., VázquezOvando, A., Salvador-Figueroa, M., \& Ovando-Medina, I. (2016). Reproductive biology of the biofuel plant Jatropha curcas in its center of origin. PeerJ, 4, e1819. http://dx.doi.org/10.7717/peerj.1819

Salvador-Figueroa, M., Magaña-Ramos, J., Vázquez-Ovando, A., AdrianoAnaya, L., \& Ovando-Medina, I. (2014). Genetic diversity and structure of Jatropha curcas L. in its centre of origin. Plant Genetic Research, 13, 9-17.

Saturnino, H. M., Pacheco, D. D., Kakida, J., Tominaga, N., \& Goncalvez, N. P. (2005). Cultura do pinhao-manso (Jatropha curcas L.). Informe Agropecuario, 26, 44-78.

Waelti, M. O., Page, P. A., Widmer, A., \& Schiestl, F. P. (2009). How to be an attractive male: floral dimorphism and attractiveness to pollinators in a dioecious plant. BMC Evolutionary Biology, 9, 190.

Whitney, H. M., \& Federle, W. (2012). Biomechanics of plant-insect interactions. Current Opinion of Plant Biology, 16, 1-7. 